\title{
Ibu Fatimah dalam Pergumulan Karakter Birokratis dan Profesional
}

\section{Syifa Masna Raisalah*}

Fakultas Ilmu Pendidikan, Universitas Negeri Malang

Universitas Negeri Malang Gedung E1, Jalan Semarang No.5, Sumbersari, Lowokwaru, Kota Malang, Jawa Timur, Indonesia

*Corresponding Author.e-mail: syifaraisa@gmail.com

\begin{abstract}
Abstrak
Penelitian ini bertujuan untuk mendeskripsikan perjuangan Ibu Fatimah dalam memerankan karakter profesional dan karakter birokratis secara efektif, di mana karakter birokratis yang kaku dipandang kontra produktif dengan karakter profesional yang dimiliki oleh guru sebagai tenaga pendidik di Sekolah Dasar Negeri AA 1 Malang, namun akhirnya dapat diselaraskan oleh Ibu Fatimah selaku agen perubahan. Data penelitian kualitatif dengan desain studi kasus ini dikumpulkan melalui wawancara dan studi dokumen serta dianalisis menggunakan model analisis kualitatif interaktif. Temuan penelitian menunjukkan bahwa Ibu Fatimah dengan pengalaman dan karakter birokratis dan professional yang dimilikinya berhasil mengubah budaya dan kinerja guru yang rendah, tidak inovatif, tidak memiliki harapan yang tinggi terhadap keberhasilan peserta didik menjadi guru yang professional, inovatif dan memiliki harapan yang tinggi terhadap kesuksesan peserta didik dan juga mengubah paradigma guru yang menerima hak/gaji dengan menunaikan kewajiban seadanya. Untuk penelitian lebih lanjut disarankan agar peneliti berikutnya dapat menggunakan solusi yang lebih fleksibel dalam mengatasi permasalahan yang terkait dengan pengelolaan karakteristik organisasi birokrasi dan profesional di sekolah.
\end{abstract}

Kata Kunci: Ibu Fatimah, karakter birokratis, karakter profesional

\section{Ibu Fatimah in the Struggle for Bureaucratic and Professional Character}

\begin{abstract}
This study aims at describing the struggle of Ibu Fatimah in playing the roles of both bureaucratic and professional characters effectively in which bureaucratic character is regarded as contra-productive with a professional character that is owned by teachers as educators at Elementary School AA 1 Malang. However, all the obstacles could be handled by Ibu Fatimah as the agent of change. The qualitative data of this study collected through interviews and document analysis and analyzed using an interactive analysis model. The findings indicate that Ibu Fatimah with her huge experience and having both bureaucratic and professional characters successfully changed the culture and performance of the teachers which were low performance, not innovative, and did not have high expectation on the success of their students, to be professional and innovative teachers as well as having high expectation on the success of their students. She also could change teachers' paradigm that only demanded rights by doing mediocre obligations. For further research, it is recommended to use a more flexible solution to overcome issues regarding how to manage the characteristics of bureaucratic and professional organizations.
\end{abstract}

Keywords: Ibu Fatimah, bureaucratic character, professional character

How to Cite: Raisalah, S. M. (2021). Ibu Fatimah dalam pergumulan karakter birokratis dan profesional. Jurnal Penelitian Ilmu Pendidikan, 14(1), 31-40. doi:https://doi.org/10.21831/jpipfip.v14i1.34078.

Received 25-08-2020; Received in revised from 25-08-2020; Accepted 07-01-2021

This is an open-access article under the $\mathrm{CC}-\mathrm{BY}-\mathrm{SA}$ license. 


\section{PENDAHULUAN}

Kualitas manajemen pendidikan khususnya pengelolaan kepemimpinan sekolah merupakan faktor yang sangat penting dalam reformasi sekolah (Mulcahy, 2019). Farah (2013) melaporkan hasil telaahnya terhadap karakteristik kepala sekolah efektif. Farah mengatakan bahwa mengelola sekolah seperti mengatur sebuah negara sehingga kepala sekolah pasti adalah seorang politikus, ahli ekonomi, psikiater dan sosiolog. Keaneka ragaman budaya, etnis, gender, dan agama dari populasi sekolah memerlukan pemenuhan atas semua kebutuhan mereka. Dalam konteks manajemen sekolah, kepemimpinan kepala sekolah menjadi kunci keberhasilan lembaga pendidikan baik sebagai organisasi birokrasi maupun organisasi professional.

Birokrasi merupakan salah satu karakteristik organisasi yang berasal dari dua kata "burreau" artinya kantor/meja tulis, dan "cratein" artinya mengatur. Istilah tersebut merujuk pada sistematika kegiatan kerja yang diatur oleh suatu kantor melalui kegiatan kerja/administrasi (Ernawan, 1988). Terdapat rantai komando birokrsi yaitu hierarki kewenangan dari atas ke bawah. Menurut Weber (1947), birokrasi merupakan suatu bentuk organisasi dimana penerapannya berhubungan dengan tujuan organisasi dan memiliki sistem otoritas secara rasional disertai aturan dan pemetaan pekerjaan bagi anggotanya. Sehingga, dapat dikatakan bahwa birokrasi merupakan struktur dengan serangkaian prosedur atau aturan bersifat tetap dan memiliki sistem rasional yang dirancang untuk melaksanakan kebijakan publik secara efektif dan efisien.

Beberapa ciri dari organisasi dengan karakteristik birokrasi adalah 1) terdapat jabatan administrasi yang disusun secara hierarkis; 2) setiap jabatan dipegang oleh orang yang memiliki kompetensi tertentu; 3) pegawai negeri ditentukan berdasarkan kualifikasi teknik dengan bukti ijazah atau melalui ujian; 4) pegawai negeri menerima gaji tetap sesuai dengan pangkat / kedudukan; 5) pekerjaan merupakan karier terbatas (pegawai negeri); 5) para pejabat tidak memiliki kantor sendiri; 6) para pejabat sebagai subjek yang mengontrol dan mendisiplinkan; dan 7) promosi didasarkan pada pertimbangan kemampuan di atas rata-rata. Lebih lanjut, Weber (1947) memaparkan karakteristik ideal yaitu 1) kerja ketat berdasarkan peraturan; 2) kaku dan sederhana; 3) pengaturan dari atas ke bawah; 4) memiliki tugas khusus; 5) diselenggarakan secara resmi; 6) berdasarkan logika; 7) sentralisasi; 8) disiplin; 9) terstruktur; dan 10) tanpa pandang bulu.

Birokrasi adalah bentuk efektif manajemen dalam organisasi yang memerlukan rasionalitas, menghilangkan kekacauan dan mencegah ambiguitas (Aydın, 2010). Secara umum, birokrasi adalah proses mengatur tindakan dan transaksi sesuai dengan aturan-aturan yang objektif dan rasional. Ketika birokrasi menunjukkan eksistensinya dalam banyak organisasi, Bursalığlu (2012) mengkarakteristikkan sekolah sebagai institusi birokrasi yang mempertimbangkan birokrasi sebagai satu dari ciri uniknya. Karakteristik struktur birokrasi di sekolah dapat digambarkan sebagai berikut: i) membangun divisi pekerja berdasarkan kompetensi dalam membagi tupoksi yang mendukung spesialisasi; ii) guru-guru bertanggungjawab kepada kepala sekolah dan koordinator-koordinator kelompok; iii) hukum dan aturan membatasi; iv) tenaga kependidikan menunjukkan keadilan dan koherensi mereka; v) orang yang bekerja di posisi khusus di sekolah menunjukkan kompetensi kerja dan kualifikasi profesional berdasarkan keahlian. Birokrasi adalah fenomena sosiologis yang dikembangkan untuk mencapai hasil-hasil yang diinginkan, dan proyek yang mengatur semua aktivitas manusia mencakup sejarah peradaban. Sekolah-sekolah, tempat dimana kita menghabiskan sebagian besar hidup kita, adalah juga salah satu dari bentuk-bentuk birokrasi (Yücel, 1999).

Menurut banyak literatur, dapat dikatakan bahwa birokrasi bisa jadi menghalangi namun juga efektif, dan sebenarnya tidak benar mempertahankannya pada level yang sangat ketat atau ramping. Craig (1995) menyatakan bahwa di Jepang birokrasi mendukung inovasi dan menyediakan produksi yang lebih cepat; Adler and Borys (1996) menemukan beberapa tipe organisasi yang birokrasinya bisa jadi penghalang atau fungsional. Dalam studi empiris (eksperimen dan observasi) yang dilakukan oleh Hoy and Sweetland (2000), ditemukan bahwa memungkinkan untuk memiliki hierarki dan struktur formal yang akan menghambat pendidikan dan pembelajaran di sekolah. Sekolah pada umumnya tidak secara sempurna bersifat birokratis atau non birokratis. Karakteristik birokratis yang berbeda dari organisasi-organisasi yang berbeda pula dapat menjadi sumber manajemen spesifik organisasi, sehingga dapat dikatakan bahwa karakteristik birokratis bisa jadi tidak sama pada level yang sama di setiap sekolah, dan hasil-hasil positif dan negatif tidak dapat dikumpulkan dari faktor-faktor yang 
sama. Hoy dan Miskel (2010) menyampaikan, selain kontribusi karakteristik birokrasi, terdapat pula beberapa efek samping; i) ketika rasionalitas menjadi hasil positif untuk memastikan obyektivitas, hal ini dapat menyebabkan gangguan yang mengancam semua terlepas dari kontribusi yang mereka berikan terhadap organisasi; ii) hierarki kewenangan dapat mengarah kepada komunikasi yang terhambat ketika melakukan komplain kedisiplinan dan koordinasi; iii) ketika melakukan kontinuitas dan keseragaman, atura-aturan dapat menyebabkan organisasi semakin ketat mengakibatkan upaya untuk mematuhi aturan daripada tujuan; iv) orientasi kerja, pada satu sisi, dapat menciptakan insentif bagi karyawan; disisi lain, dapat menyebabkan konflik antara kesuksesan dan senioritas yang berkaitan prinsip-prinsip birokrasi. Staf pengajar di sekolah-sekolah, sebagai lembaga birokratis, terdiri dari guru-guru yang mempersepsikan diri mereka sebagai para ahli di bidangnya. Tidak ada jawaban pasti dan sederhana terhadap pertanyaan apakah sekolah sebaiknya dilonggarkan atau terstruktur baik dalam konteks birokrasi, sebab karakteristik lingkungannya mengikat (Aydın, 2010). Karena salah satu karakteristik lingkungan yang menentukan bagaimana birokrasi seharusnya, adalah keahlian para guru dan kepala sekolah. Hal ini dapat dilihat dari bagaimana organisasi pendidikan belum memahami betapa pentingnya memberi tempat bagi keahlian para ahli (Bursalığlu, 2012) mempengaruhi profesionalisme para guru dan kepala sekolah, dan juga bagaimana mereka membentuk karakteristik birokratis. Masalah-masalah tersebut menjadi isu yang perlu diteliti. Adalah mungkin untuk mengatakan bahwa profesionalisme berkaitan dengan sikap dan perilaku yang dikembangkan oleh seseorang terhadap pekerjaan dan mutu kerjanya (Güven, 2010). Dalam konteks profesi mengajar, profesionalisme dapat didefinisikan sebagai keefektifan guru dalam menentukan kualitas kegiatan belajar dan mengajar (Day, 2002). Hal ini dapat dikemukakan bahwa ada hubungan antara profesionalisme dan memiliki pengetahuan tentang bidang, tindakan berkaitan dengan layanan etika, mencoba untuk mempertemukan kebutuhan-kebutuhan dari sasaran di sector layanan, mengembangkan komitmen yang kuat terhadap profesi, dan dapat bertindak secara mandiri ketika memenuhi persyaratan-persyaratan pekerjaan (Cerit, 2012). Hoy dan Miskel (2010) menegaskan bahwa para guru dapat menunjukkan kemandirian professional ketika struktur birokrasi sekolah efektif, dan perilaku professional tidak dibatasi oleh aturan-aturan yang kaku. Dalam struktur birokrasi sekolah yang efektif, para guru merasa diberdayakan, berkomunikasi secara internal dengan para kolega mereka, dan memiliki rasa berbeda dan menghargai perbedaan (Kepenekçi (Karaman), 1998). Bayhan (2011) menemukan bahwa struktur sekolah yang efektif menyediakan kerjasama antar guru, dan para guru saling membantu dan mendukung satu sama lainnya dalam menyelesaikan permasalahan yang mereka hadapi selama melaksanakan praktik-praktik professional, sehingga dapat dikatakan bahwa terdapat hubungan antara struktur birokrasi dan profesionalisme guru-guru. Hoy dan Sweetland (2001) menjelaskan bahwa meskipun ada pandangan yang luas tentang birokrasi yang memiliki banyak kelemahan terkait dengan para pekerja organisasi, akan tetapi birokrasi memiliki sisi positif, dan beragam struktur yang berbeda dapat dibentuk berdasarkan tingkat formalitas dan sentralisasi. Terdapat beberapa sekolah Weberian, dimana birokrasi dan profesionalisme sangat tinggi. Di satu sisi, struktur sekolah otoriter ketika birokrasinya tinggi tetapi profesionalismenya rendah. Sebaliknya, profesionalisme meningkat ketika birokrasinya rendah; dan lingkungan yang kacau akan tercipta ketika keduanya baik birokrasi maupun profesionalisme rendah.

Sekolah merupakan kumpulan para profesional untuk mencapai tujuan, sehingga disebut sebagai organisasi profesional. Profesional merupakan orang yang memiliki profesi atau pekerjaan yang dilakukan dengan memiliki kemampuan yang tinggi dan berpegang teguh kepada nilai moral yang mengarahkan serta mendasari perbuatannya. Hamalik (2004) mengemukakan pekerjaan guru adalah suatu profesi tersendiri, pekerjaan ini tidak dapat dikerjakan oleh sembarang orang tanpa memiliki keahlian sebagai seorang guru. Banyak yang pandai berbicara tertentu, namun orang itu belum dapat disebut sebagai seorang guru. Etika Profesional lebih luas dari prinsip-prinsip moral, etika tersebut mencakup prinsip perilaku untuk orang-orang profesional yang dirancang baik untuk tujuan praktis maupun untuk tujuan idealistis. Prinsip-prinsip etika diantaranya adalah: 1) Tanggung jawab profesi; 2) Kepentingan Publik; 3) Integritas; 4) Obyektivitas; 5) Kompetensi dan kehati-hatian profesional; 6) Kerahasiaan; 7) Perilaku profesional; 8) Standar teknis. Karakteristik Profesional meliputi 1) Memiliki kemampuan dan pengetahuan yang tinggi; 2) Memiliki kode etik; 3) Memiliki tanggung jawab profesi serta integritas yang tinggi; 4) Memiliki jiwa pengabdian kepada masyarakat; 
5) Memiliki kemampuan yang baik dalam perencanaan program kerja; 6) Menjadi anggota organisasi dari profesinya.

Konsep Profesional yang dikembangkan oleh Hall \& Robert (1983), adalah sebagai berikut. Pertama, afiliasi komunitas (Community affilition), menggunakan ikatan profesi sebagai acuan, termasuk di dalamnya organisasi formal atau kelompok-kelompok kolega informal sumber ide utama pekerjaan. Melalui ikatan profesi ini para profesional dapat membangun kesadaran profesi. Kedua, kebutuhan untuk mandiri (autonomy demand), merupakan suatu pandangan bahwa seseorang yang profesional harus mampu membuat keputusan sendiri tanpa tekanan dari pihak lain (pemerintah, klien, mereka yang bukan anggota profesi). Setiap adanya campur tangan (intervensi) yang datang dari luar, dianggap sebagai hambatan terhadap kemandirian secara profesional. Ketiga, keyakinan terhadap peraturan sendiri/profesi (belief self regulation), yang paling berwenang dalam menilai pekerjaan profesional adalah rekan sesama profesi, bukan "orang luar" yang tidak mempunyai kompetensi dalam bidang ilmu dan pekerjaan mereka. Keempat, dedikasi pada profesi, dicerminkan dari dedikasi profesional dengan menggunakan pengetahuan dan kecakapan yang dimiliki. Keteguhan tetap untuk melaksanakan pekerjaan meskipun imbalan ekstrinsik dipandang berkurang. Sikap ini merupakan ekspresi dari aktualisasi diri secara totalitas terhadap pekerjaan. Pekerjaan didefinisikan sebagai tujuan. Totalitas ini sudah menjadi komitmen pribadi, sehingga kompensasi utama yang diharapkan dari pekerjaan adalah kepuasan rohani dan setelah itu baru materi. Kelima, kewajiban sosial (social obligation), merupakan pandangan tentang pentingnya profesi serta manfaat yang diperoleh baik oleh masyarakat maupun profesional karena adanya pekerjaan tersebut.

Berkaitan dengan keberadaan sekolah sebagai organisasi birokrasi dan professional serta bagaimana interaksi keduanya dan upaya untuk menegakkannya secara tepat dan proporsional, peneliti melakukan studi pendahuluan di salah satu sekolah dasar negeri yaitu SDN AA 1 Kota Malang untuk melihat lebih dekat tentang permasalahan yang dihadapi oleh guru dalam konteks sekolah sebagai organisasi birokrasi dan professional. Di SDN AA 1 Kota Malang ada seorang guru bernama Ibu Fatimah, sebelum menjadi guru PNS di sekolah ini, beliau adalah seorang guru non PNS yang bekerja di salah satu sekolah swasta di Kota Malang juga. Perbedaan pola kerja di sekolah swasta yang berbasis kinerja dan kompetensi yang unggul dalam melaksanakan tugas profesinya dengan lingkungan sekolah negeri yang menurutnya "guru-guru bekerja apa adanya, tidak memiliki inisiatif untuk menerapkan inovasi agar peserta didik semakin antusias belajar dan menghasilkan prestasi belajar yang semakin baik dari waktu ke waktu". Kesenjangan yang sangat kontradiktif antara dua lingkungan kerja ini menarik untuk diteliti lebih dalam. Oleh karena itu, peneliti melakukan penelitian studi kasus ini terhadap Ibu Fatimah dalam konteks sekolah sebagai organisasi birokrasi dan pofesional. Dalam hal ini, akan meneropong bagaimana perjuangan seorang Ibu Fatimah dalam memerankan karakter birokratis dan professional secara tepat dan pengaruhnya terhadap kolega sesama guru di lingkungan kerjanya di SDN AA 1 Kota Malang.

\section{METODE}

Penelitian ini bertujuan untuk mendapatkan gambaran tentang perjuangan Ibu Fatimah dalam memerankan karakter birokratis dan professional di sekolah dengan menggunakan pendekatan kualitatif. Alasan menggunakan pendekatan ini karena pendekatan kualitatif menyediakan peluangpeluang yang memungkinkan untuk memperoleh data-data yang akurat tentang perjuangan Ibu Fatimah ketika melakukan perubahan dalam konteks sekolah sebagai organisasi birokratis dan profesional. Babbie (1995) menyatakan bahwa penelitian lapangan menawarkan manfaat terhadap penggalian kehidupan sosial dalam habitat alaminya. Manfaat menggunakan pendekatan kualitatif sangat didukung oleh banyak penelitian empiris (Anderson \& Jones, 2000; Creswell \& Clark, 2007; Maxwell, 2005). Penelitian kualitatif dikarakteristikkan dengan paradigma interpretatif yang berfokus pada pengalaman pribadi subjek penelitian dan memiliki makna (Creswell, 2009; Sugiyono, 2014). Pendekatan kualitatif ini digunakan untuk melakukan eksplorasi secara mendalam terhadap program, kejadian, proses, aktifitas yang dilakukan oleh seseorang atau lebih dan peneliti melakukan pengumpulan data dengan menggunakan berbagai prosedur dan dalam waktu yang berkesinambungan, oleh karenanya desain penelitian ini menggunakan studi kasus (case study) (Sugiyono, 2014). 
Dalam penelitian kualitatif, peneliti sendiri yang bertindak sebagai instrumen kunci yang melakukan wawancara dengan informan. Peneliti menyiapkan alat bantu dalam melakukan pengambilan data seperti alat perekam, handphone android dan catatan lapangan. Untuk mengumpulkan data, peneliti hanya menggunakan dua teknik pengumpulan data, yaitu wawancara dan studi dokumen. Peneliti tidak dapat melakukan pengamatan langsung ke sekolah disebabkan kondisi karantina Belajar Dari Rumah untuk antisipasi pencegahan penyebaran Covid-19. Pengumpulan data melalui wawancara dan studi dokumen pun hanya dapat dilakukan melalui percakapan telepon, aplikasi whatsapp, zoom dan mempelajari data sekolah melalui Dapodik Kemendikbud. Peneliti mewawancarai Ibu Fatimah sebagai informan kunci dalam penelitian ini, informan lain adalah kepala sekolah dan wakil kepala sekolah. Untuk menghargai permintaan para informan, nama lembaga sekolah dalam artikel ini merupakan nama lembaga sekolah yang telah disamarkan/nama alias (pseudonym) (Moleong, 2005).

Data penelitian dianalisis menggunakan model analisis data interaktif yang disarankan oleh Miles \& Huberman (1994). Model analisis ini terdiri dari tiga langkah, yaitu: reduksi data, penyajian data, kesimpulan dan verifikasi. Ketiga langkah tersebut dilakukan secara interaktif atau berlangsung secara serentak. Untuk mengecek keabsahan data penelitian, peneliti melakukan trianggulasi teknik pengumpulan data, yakni melihat kesamaan data yang diperoleh melalui wawancara dan studi dokumen dan trianggulasi sumber data yakni mengkonfirmasi data kepada para informan.

\section{Hasil}

\section{HASIL DAN PEMBAHASAN}

Berdasarkan data yang dikumpulkan, peneliti menemukan kisah perjuangan Ibu Fatimah dalam konteks sekolah sebagai organisasi birokrasi dan organisasi professional yang dipaparkan sebagai berikut.

Sebelum menjadi tenaga pengajar di SDN AA 1 Kota Malang, Ibu Fatimah adalah seorang guru di sekolah swasta yaitu Madrasah Ibtidaiyah Pahlawan Indonesia (MIPI), tepatnya sebelum beliau beralih profesi menjadi seorang guru Pegawai Negeri Sipil (PNS). Guru ini mengalami depresi akibat lingkungan kerja yang sangat berbeda. Sebelumnya di MIPI, budaya disiplin, kreatif, inovatif, dan komunikasi yang baik sangat dijunjung, sehingga para guru berlomba-lomba menjadi yang terbaik dalam melayani siswa (Jaszczyszyn \& Lewkowicz, 2019). Selain itu, komunikasi yang baik antar guru dan dengan kepala sekolah, terjalin dengan baik, dimana para pendidik tidak mengedepankan senioritas guru lama terhadap guru baru. Namun, ketika beliau akhirnya diterima sebagai guru PNS dan ditempatkan pertama kali di daerah Bangil, Pasuruan, Ibu Fatimah mengalami kondisi stress disebabkan oleh kondisi lingkungan kerja yang sangat kontradiktif dengan kondisi yang dialami sebelumnya, yaitu kinerja guru yang lambat, sekolah yang kumuh, dan tingkat antusiasme mengajar yang sangat rendah. Kondisi tersebut memaksa Ibu Fatimah untuk menerima terapi dan mengkonsumsi obat dari seorang psikiater. Ibu Fatimah diindikasi mengalami cultural shock yang cukup berat, dan membutuhkan waktu lebih lama untuk beradaptasi. Perbedaan budaya ini cukup sulit diterima karena Ibu Fatimah juga berasal dari keluarga militer, dimana disiplin merupakan budaya kunci yang diajarkan oleh orang tua beliau.

Meskipun dalam kondisi demikian, Ibu Fatimah tetap berusaha bekerja menunjukkan kinerjanya secara konsisten. Ketika proses adaptasi beliau dengan sekolah di Bangil mulai menampakkan hasilnya, beliau dipindah tugaskan ke SDN AA 1 Kota Malang. Di sekolah yang baru ini ujian yang dihadapi oleh Ibu Fatimah tidak berhenti bahkan semakin berat. Adanya senioritas yang kental dari para guru senior menyebabkan sekolah tidak dapat berkembang maju. Guru-guru di sekolah ini bekerja dengan lambat, tidak kreatif, apalagi melakukan inovasi. Selain itu, kedisiplinan kerja juga bukan merupakan bagian dari budaya sekolah tersebut. Banyak guru yang tidak menyerahkan RPP, Prota, maupun Promes dengan tepat waktu. Kepala sekolah secara tidak langsung terpaksa menunggu para guru untuk menyelesaikannya dalam waktu cukup lama sementara kegiatan pembelajaran terus berlanjut. Setiap kali Ibu Fatimah ingin melakukan inovasi, dia menghadapi komentar pedas dari guru-guru senior yang merasa tidak dihargai. Baginya tidak ada satu pun yang dapat diandalkan, dalam konteks ini guru adalah sebuah profesi yang menuntut keprofesionalan, sedangkan di lapangan mayoritas guru dinilai tidak profesional. Mereka merasa sudah berada pada 
zona nyaman dengan menerima gaji yang didapatkan setiap bulan. Selain itu, para guru tersebut telah merasa melaksanakan kewajiban sebagai guru kelas sesuai dengan penempatan oleh kepala sekolah. Dalam hal ini, para guru merasa telah bekerja sesuai dengan tugas pokok dan fungsi jabatan mereka.

Kondisi yang dipaparkan di atas, sangat berbeda dengan Ibu Fatimah yang saat itu masih sebagai guru baru dengan semangat berkobar untuk memajukan kualitas pendidikan dan peserta didik di SDN AA 1 Kota Malang. Ibu Fatimah tidak ingin hanya sekedar bekerja untuk memenuhi kewajiban jabatan yang dipegang, maupun menerima gaji dengan usaha yang tidak maksimal. Oleh karena itu, pada awal ditempatkan sebagai guru baru di sekolah tersebut, beliau berdiskusi dengan kepala sekolah dan banyak mengajukan ide-ide untuk mengubah sekolah ke arah yang lebih baik. Namun, niat baik Ibu Fatimah ditentang oleh banyak guru dan mereka berusaha menekan Ibu Fatimah. Beruntung Ibu Fatimah orang yang tegas dan tidak mudah terpengaruh, sehingga akhirnya mampu mendobrak budaya mengajar 'seadanya' di sekolah tersebut. Perlahan tapi pasti, pada akhirnya Ibu Fatimah ditunjuk sebagai wakil kepala sekolah bidang kurikulum di SDN AA 1 Kota Malang mendampingi kepala sekolah mengatur pembelajaran dan manajemen sekolah. Peran Ibu Fatimah sebagai Wakasek Kurikulum ini menjadi starting point bagi SDN AA 1 bangkit untuk melakukan perubahan-perubahan ke arah yang lebih baik hingga detik ini.

\section{Pembahasan}

Berdasarkan temuan penelitian yang telah dipaparkan di atas, dapat dilihat adanya pertentangan antara karakteristik birokrasi dan karakteristik profesional. Para guru senior di SDN AA 1 Kota Malang menggunakan asas karakteristik birokrasi, sehingga muncul kinerja 'yang penting mengerjakan' yaitu dengan memenuhi tugas sebagai guru kelas. Namun demikian, karena kurangnya semangat dan dengan landasan pengabdian masyarakat, maka pekerjaan dilakukan semata-mata untuk menyelesaikan tanggungan atau gugur kewajiban. Kondisi ini yang perlu diubah dalam meningkatkan kualitas pendidikan (Helterbran, 2016).

Selain itu, guru senior yang ada di sekolah tersebut, bersama dengan guru lainnya kurang menanamkan paradigma guru sebagai pendidik. Sehingga, selain kurangnya etos kerja dalam rangka sharing ilmu pengetahuan, para guru juga tidak berusaha keras untuk menerapkan jiwa disiplin kepada siswa. Tidak inovatifnya guru terlihat dari penolakan terhadap teknologi yang saat ini tengah berkembang. Awal kehadiran Ibu Fatimah di sekolah tersebut, hanya 1 hingga 2 guru yang mampu mengoperasikan komputer dan liquid crystal display $(L C D)$. Sedangkan saat ini penggunaan teknologi mutlak adanya, disebabkan banyaknya informasi yang bisa diberikan kepada siswa melalui penerapan teknologi. Di samping itu, dengan guru mampu mengoperasikan teknologi seperti komputer, maka secara tidak langsung, guru dapat menjadi contoh bagi siswa, baik dalam pengoperasian maupun proses penyaringan informasi. Pengadaan komputer maupun LCD di kelas merupakan salah satu upaya pemerataan fasilitas pendidikan di sekolah (Iskandar, liputan6.com, 2018). Keengganan guru untuk maju adalah suatu hal yang secara tidak langsung menghambat program pemerataan pendidikan. Fasilitas telah diberikan, namun penggunaannya tidak maksimal, sehingga Ibu Fatimah yang menjunjung profesionalisme menjadi semakin tertekan.

Berbeda halnya dengan motivasi dan etos kerja Ibu Fatimah yang telah terbiasa bekerja secara profesional di MIPI yaitu sekolah swasta sebelumnya. Di sekolah swasta, sekolah lebih cepat berkembang dan maju disebabkan adanya inovasi dan kreasi dari para guru dimana hierarki tidak menjadi prioritas, namun ide baru untuk meningkatkan kualitas pendidikan di sekolah yang lebih ditonjolkan. Selain itu, permasalahan gaji yang cenderung tidak pasti seperti di SD Negeri, menyebabkan Ibu Fatimah terbiasa bekerja lebih untuk mendapatkan gaji dan pendapatan yang tinggi. Sekolah swasta juga perlu berlomba-lomba menarik calon peserta didik agar tidak kalah dengan sekolah swasta yang lain. Namun demikian, sepanjang pengalaman yang didapatkan, Ibu Fatimah pada awalnya tidak mendapat gaji tinggi di MIPI. Namun kondisi berubah yaitu saat hasil kerja kerasnya beserta guru lain membawa perkembangan dan kemajuan yang sangat pesat terhadap sekolah (Hurley, 2016). Aspek ini dapat terlihat jelas melalui bertambahnya pendaftar peserta didik baru setiap tahunnya dan kepercayaan masyarakat yang semakin besar, hingga pada akhirnya berkontribusi pada kenaikan gaji dan pendapatan beliau. 
Aspek profesionalisme ini tidak semata-mata mencari gaji yang tinggi, namun lebih kepada memberikan pelayanan maksimal kepada siswa, dimana sekolah merupakan tempat bagi para siswa untuk mendapatkan pendidikan yang berkualitas. Berbeda dengan kondisi di SDN AA 1 Malang, jiwa ini belum dimiliki oleh mayoritas guru pada saat itu. Permasalahan ini yang kemudian menyeruak sehingga perlu adanya pemecahan masalah (problem solving) antara Ibu Fatimah, guru, dan kepala sekolah. Permasalahan dan metode pemecahan masalah yang ditempuh di SDN AA 1 Malang dipaparkan berikut ini.

Selain adanya faktor gaji, keberadaan hieararki senioritas di sini tidak bisa dipangkas dengan tegas oleh kepala sekolah, terlepas dari posisi beliau sebagai pimpinan di sekolah. Hal ini disebabkan hierarki yang terbentuk adalah melalui senioritas kerja, bukan atasan dan bawahan. Senioritas kerja ini muncul karena banyak guru senior telah bekerja puluhan tahun di sekolah tersebut sehingga tidak merasa perlu berubah. Di samping itu, keberadaan guru senior lebih lama dibandingkan masa jabatan yang telah dilalui kepala sekolah. Situasi ini yang kemudian membuat setiap guru baru yang dipindah tugaskan ke sekolah tersebut merasa tidak nyaman awalnya, namun kemudian terbawa arus dan akhirnya turut terbawa arus budaya kerja yang apa adanya. Beberapa guru baru pada awalnya ingin memberikan masukan, mengkritisi, ataupun berinovasi, namun ketika ada sedikit perbedaan, guru senior menunjukkan ketidak sukaan mereka, sehingga proses komunikasi terputus. Hal ini juga terjadi kepada Ibu Fatimah, namun berbeda dengan guru-guru baru sebelumnya, Ibu Fatimah tidak ingin tunduk dengan senioritas yang tidak sehat ini. Selain itu, beliau mendedikasikan diri untuk menjadi guru PNS, bukan semata-mata karena gaji, namun karena idealisme beliau untuk memajukan pendidikan. Sehingga, respon negatif yang diterima Ibu Fatimah tidak membuat beliau mundur. Kondisi ini dibenarkan oleh beberapa temuan penelitian terdahulu mengenai karakteristik dari sekolah baik sebagai organisasi birokratis maupun professional (Hoy \& Miskel, 2010; Güven, 2010; Hoy \& Sweetland, 2001)

Selain kondisi di atas, kepribadian kepala sekolah di SDN AA 1 Malang kurang mendukung untuk terjadinya perubahan di sekolah tersebut. Hal ini dikarenakan kepala sekolah juga terlalu bersikap kebapakan dan bersifat kejawen, dimana lebih banyak sungkan dibandingkan bersikap tegas dalam memimpin. Saat dikonfirmasi, kepala sekolah menganggap tindakan yang diambil oleh beliau adalah bentuk penghormatan kepada para guru senior, serta dalam rangka mempertahankan keharmonisan lingkungan kolegialitas pengajar di SDN AA 1 Malang. Kondisi ini kemudian menumbuhkan kegelisahan dalam diri Ibu Fatimah, sehingga akhirnya, secara profesional dan hierarki, beliau berusaha membenahi hubungan dan kinerja dengan para guru.

Langkah yang dilakukan oleh Ibu Fatimah adalah meminta Kepala Sekolah untuk melakukan mediasi dengan setiap guru yang bermasalah bersama beliau. Dalam mediasi tersebut, Kepala Sekolah bersikap sebagai moderator dan menunjukkan posisinya sebagai pemimpin sekolah. Proses ini merupakan sebuah langkah besar, baik bagi para guru senior, Ibu Fatimah, maupun kepala sekolah sendiri. Perubahan ini membutuhkan keterbukaan, lapang dada, dan pikiran terbuka dari semua pihak.

Proses mediasi ini tidak berjalan dengan mudah. Pada mulanya, guru-guru yang bersangkutan diundang untuk menghadap kepala sekolah, tidak semua berkenan untuk hadir. Lebih banyak guru yang tidak hadir, daripada guru yang berkenan. Setelah satu guru berhasil menemukan pemecahan masalah bersama, maka guru senior lain mulai terbuka dan akhirnya perlahan mulai berkenan menghadiri pertemuan untuk mediasi. Namun demikian, proses mediasi dengan satu guru tidak selalu berhasil dalam sekali pertemuan, terkadang membutuhkan 2 hingga 3 kali diskusi. Setelah itu, jika dalam proses mediasi terjadi deadlock, maka Kepala Sekolah membawa permasalahan ini ke Pengawas Sekolah untuk kemudian dicarikan solusinya. Melalui cara tersebut, beberapa guru telah berubah menjadi lebih kooperatif, namun ada guru yang masih mempertahankan pola awal dengan kinerja yang tidak profesional.

Jika dicermati secara umum, kepentingan yang dibawa tampak hanya menonjolkan kepentingan Ibu Fatimah hingga harus diadakan proses mediasi. Tetapi sesungguhnya masalah tersebut tidak hanya menyangkut Ibu Fatimah, namun juga guru-guru senior dan guru-guru baru lain yang tidak mampu berkomunikasi dan menyuarakan aspirasi mereka dengan baik. Selain itu, kepentingan yang lebih utama adalah adanya usaha mengubah iklim pendidikan di SDN AA 1 Malang. Melalui pertemuan ini, semua pihak yang akan mendapatkan manfaatnya; kepala sekolah, guru-guru dan semua peserta didik. 
Seiring berjalannya waktu, guru-guru mulai tergugah menjadi lebih inovatif dan berdedikasi mengabdi bagi pendidikan dan kemajuan peserta didik, sehingga profesionalisme di sekolah mulai nampak dan terbukti dengan adanya perbaikan sekolah dan standar kelulusan yang meningkat. Secara birokrasi pun, posisi Kepala Sekolah sebagai pemimpin dan Ibu Fatimah sebagai wakil kepala sekolah bidang kurikulum lebih berperan menjalankan tupoksi sesuai hierarkinya.

Kepala sekolah saat ini lebih memiliki wibawa dalam memimpin dan mengelola sekolah. Dimana kedua proses tersebut memang tidak mudah dibedakan atau dipisahkan (Danim \& Suparno, 2009). Kepercayaan diri kepala sekolah semakin berkembang, dimana keputusan-keputusan tampak lebih mudah diberikan untuk mendukung kemajuan pendidikan di SDN AA 1 Malang. Salah satunya adalah jika terjadi konflik dan tidak bisa diselesaikan di dalam sekolah, maka cara terbaik adalah berkonsultasi kepada pengawas. Hal ini tidak terlepas dari kewenangan dinas pendidikan dalam mengelola penempatan dan sumber daya manusia di sekolah-sekolah negeri, tidak seperti dahulu saat setiap sekolah berhak mengadakan open recruitment guru baru per lembaga (Peraturan Pemerintah No. 74, 2008).

Perkembangan ini terus berusaha dijaga untuk meningkatkan kualitas manajemen sekolah, sehingga dapat dilihat bahwa karakteristik birokrasi yang salah satunya menekankan pada pelayanan publik dalam artian memberikan pelayanan terbaik bagi peserta didik; mendapatkan dukungan oleh karakter profesional yang mendorong seseorang untuk bekerja dengan motivasi kerja yang tinggi (Hamalik, 2004).

\section{PENUTUP}

Berdasarkan hasil penelitian dan pembahasan di atas, dapat disimpulkan bahwa manajemen sekolah yaitu proses pendayagunaan sumber daya manusia sebagai penyelenggara pendidikan secara efektif telah mengalami perubahan dan perkembangan di SDN AA 1 Kota Malang. Karakteristik sekolah sebagai organisasi birokrasi yang syarat dengan unsur-unsur hierarki, gaji dan pola kerja sesuai jabatan terlihat jelas dalam upaya Ibu Fatimah mengubah dan melakukan inovasi di sekolah tersebut. Demikian pula, karakteristik profesional yang berwujud pengabdian masyarakat, tidak selalu berorientasi pada besar kecilnya gaji yang diterima, sikap kolegial-partisipatif, dan semangat tinggi telah berhasil ditanamkan oleh Ibu Fatimah sebagai agen perubahan bersama kepala sekolah sehingga karakter professional ini menjadi budaya kerja guru-guru di SDN AA 1 Kota Malang.

Solusi yang dilakukan oleh kepala sekolah dan waka kurikulum merupakan salah satu bentuk manajemen sekolah yang menggabungkan dua karakteristik. Apabila dilihat lebih seksama, maka akan tampak penanganan atau pemecahan masalah yang tidak kaku, tidak berfokus pada satu pemenuhan karakteristik yang menjadi satu-satunya solusi, namun lebih bersifat situasional dan fleksibel.

Berdasarkan kesimpulan dari hasil penelitian tersebut, disarankan kepada peneliti berikutnya untuk meneliti faktor situasional yang memadukan dua karakteristik berbeda, sebagaimana dalam kasus ini terdapat pemecahan masalah yang tidak hanya berfokus kepada satu karakteristik. Penelitian lebih lanjut akan memperkaya referensi dalam menyelesaikan permasalahan manajemen sekolah yang meliputi hubungan kepemimpinan dan bawahan dengan karakteristik dan latar belakang yang berbeda-beda di latar penelitian yang berbeda pula.

\section{UCAPAN TERIMA KASIH}

Peneliti menyampaikan terima kasih kepada para informan dan pihak SDN AA 1 Malang atas kesediaannya menjadi objek penelitian.

\section{DAFTAR PUSTAKA}

Adler, P. S. \& Borys, B. (1996). Two types of bureaucracy: Enabling and coercive. Administrative Science Quarterly, 41(1), 61-89. 
Anderson, G.L \& Jones, F. (2000). Knowledge generation in educational administration from the inside out: the promise and perils of site-based, administrator research. Educational Administration Quarterly, 36(3), 428-464.

Aydın, M. (2010). Eğitim yönetimi. Ankara: Hatipoğlu Basım.

Babbie, E. (1995). The practice of social research. (Seventh ed). Belmont, CA: Wadsworth.

Bayhan, G. (2011). Öğretmenlerin profesyonelliğinin incelenmesi. (Yayımlanmamış doktora tezi). Marmara Üniversitesi Eğitim Bilimleri Enstitüsü, İstanbul.

Bursalıoğlu, Z. (2012). Okul yönetiminde yeni yapı ve davranış. Ankara: Pegem Yayıncılık.

Cerit, Y. (2012). Okulun bürokratik yapisi ile sinif öğretmenlerinin profesyonel davranişlari arasindaki ilişki. Kuram ve Uygulamada Ĕ̆itim Yönetimi, 4(8), 497-521.

Craig, T. (1995). Achieving innovation through bureaucracy: lessons from the japanese brewing industry. California Management Review, 38(1), 8-36.

Creswell, J.W., \& Clark, V. L. P. (2007). Designing and conducting mixed methods research. (Third ed). California: Sage Publication.

Creswell, J.W. (2009). Research design: qualitative, quantitative, and mixed methods approaches. (Third ed). California: Sage Publication.

Danim, S. \& Suparno. (2009). Manajemen dan kepemimpinan transformasional kekepalasekolahan. Jakarta: Rineka Cipta.

Day, G. (2002). The state of dracula: bureaucracy and the vampire. In Jenkins A., \& John, J (eds) Rereading Victorian Fiction. Palgrave Macmillan, London. https://doi.org/10.1057/9780230371149_6.

Ernawan, E. (1988). Peranan birokrasi terhadap peningkatan efektivitas pengambilan keputusan di perusahaan besar. (Skripsi). Tidak diterbitkan. Jakarta: Fakultas Psikologi Universitas Indonesia.

Farah, A. I. (2013). School management: characteristics of effective principal. Global Journal of Human Social Science: Linguistics \& Education, 13(3).

Güven, D. (2010). Profesyonel bir meslek olarak türkiye'de öğretmenlik. Boğaziçi Üniversitesi Eğitim Dergisi, 27(2), 13-21.

Hall, R. D., \& Robert, E. Q. (1983). Organizational theory and public policy. London: Sage Publication.

Hamalik, O. (2004). Proses belajar mengajar. Jakarta: Bumi Aksara.

Helterbran, V. (2016). Chapter 12: Teacher leadership: Overcoming "I am just a teacher" syndrome. Counterpoints, 466, 114-120. Retrieved August 24, 2020, from http://www.jstor.org/stable/45157462.

Hoy, W. K., \& Miskel, C. G. (2010). Eğitim yönetimi. (S. Turan, Çev.). Ankara: Nobel YayınDağıtım.

Hoy, W. K., \& Sweetland, S. R. (2000). School bureaucracies that work enabling, not coercive. Journal of School Leadership, 10(6), 525-41.

Hoy, W. K., \& Sweetland, S. R. (2001). Designing better schools: The meaning and measure of enabling school structures. Educational Administration Quarterly, 37(3), 296-321.

Hurley, J. (2016). Chapter 22: Teacher leadership: a new foundation of education? Counterpoints, 466, 186-196. Retrieved August 24, 2020, from http://www.jstor.org/stable/45157476.

Iskandar. (22/11/2018). Peran edutech dalam pemerataan pendidikan di Indonesia. Liputan6. Diakses pada 2017 dari https://www.liputan6.com/tekno/read/3708709/peran-edutech-dalampemerataan-pendidikan-di-indonesia

Jaszczyszyn, E., \& Lewkowicz, I. (2019). Are innovations a contribution to the professional development of teachers? In Kowalczuk-Walêdziak M., Korzeniecka-Bondar A., Danilewicz W., \& Lauwers G. (eds.), Rethinking Teacher Education for the 21st Century: Trends, Challenges and New Directions. Toronto: Verlag Barbara Budrich. doi:10.2307/j.ctvpb3xhh.20.

Kepenekçi (Karaman), Y. (1998). Bürokrasi kavramı ve türkiye eğitim sisteminde bürokrasi, İstanbul: Kültür Koleji Eğitim Vakfi Yayınları.

Maxwell, J.A. (2005). Qualitative research design: An interactive approach. (Second ed). Thousand Oaks, CA: Sage.

Miles, M. B., \& Huberman, A. M. (1994). Qualitative data analysis: An expanded sourcebook. Thousand Oaks, CA: Sage. 
Jurnal Penelitian Ilmu Pendidikan, 14 (1), 2021 - 40

Raisalah

Moleong, L.J. (2005). Metode penelitian kualitatif. (Edisi Revisi). Bandung: PT. Remaja Rosdakarya. Mulcahy, D. E. (2019). The role of the school principal in educational reform. International Journal of Leadership in Education. 28(2), 151-161.

Sugiyono. (2014). Metode penelitian manajemen. Bandung: Alfabeta.

Yücel, C. (1999). Bureaucracy and teachers' sense of power (Unpublished doctoral dissertation). Virginia Polytechnic Instituteand State University, USA.

Weber, M. (1947). The theory of social and economic organization. Massachusetts: The Free Press. 